\title{
Analysis of Wind Speed Data and Annual Energy Potential at Three locations in Iraq
}

\author{
Ali M. Rasham \\ University of Baghdad \\ College of Engineering \\ Energy Engineering Department
}

\begin{abstract}
Analysis of wind speed data and annual wind energy potential at three selected sites in Iraq has been investigated in this study. The wind speed data was collected from the Weather Underground Organization (WUO) at stations elevation. Extrapolation of stations elevations used to estimate the wind velocities at $60 \mathrm{~m}, 90 \mathrm{~m}$, and $120 \mathrm{~m}$ via wind shear law. The objectives were to analysis of wind speed data and to assess the wind energy potential for the selected sites. Computer code for MATLAB software has been developed and written to solve mathematical model. Results in the form of the measured and Weibull estimated of monthly and annual average of wind velocities $(\overline{\mathrm{V}})$, wind shear, wind velocity carrying maximum energy $\left(V_{m E}\right)$, most probable wind velocity $\left(V_{m p}\right)$, probability density function (PDF), cumulative distribution function (CDF), monthly and annual wind power density (WPD) and wind energy density (WED) were presents. At stations elevation, the (WED) was the best for Basrah, Amarah, and Nasiriyah respectively and the selected sites are suitable for off grid applications. While at selected heights it was best for Basrah, Nasiriyah, and Amarah respectively. Basrah at $(60,90,120 \mathrm{~m})$ and Nasiriyah at (120) are acceptable for connecting to power grid.
\end{abstract}

\section{Keywords}

Weibull distribution, assessment of wind resource, Wind energy potential, Analysis of wind speed data.

\section{INTRODUCTION}

Since several years, many countries have begun to use of renewable energies projects because it is clean, new energies, inexhaustible and environmentally friendly. On the other hand, it contribute to being reduce global warming, air pollution, and reduce the depletion of non-conventional fossil fuels. It is worth mentioning that the wind energy projects are considered one of the most renewable energy projects globally increasing. Nowadays, an advanced ranking are occupies by wind energy projects as compared with other renewable energy resources and conventional resources. Due to the reduction of production cost for wind energy projects and improvements of its technology as compared with traditional and renewable resources, the growing of wind energy projects was in a fast rate. Obviously, the problem of the growing demand for electricity in Iraq, leading to a move to the use of renewable energy as an alternative and successful solution to face this crisis. Efforts for assessing wind energy potential are so important in this field in order to select the appropriate sites for the installation of wind turbines. The wind's statistical models are used to analysis and assess the energy potential available for a specific sites. The wind data of three sites in the south of Iraq, Amarah, Nasiriyah, and Basrah, were collected to analysis wind speed data and to assess wind energy potential.
Majority of the studies were presented to assess the wind energy potential, wind speed characteristics, the diurnal and seasonal of wind parameters, and the electricity generation potential were analyzed by most of previous studies in many countries. It is worth mentioning that the present study is one of the important steps to assess wind speed data and wind energy potential of the selected sites in Iraq. Accordingly, the selection of suitable wind turbines for selected sites in order to install wind farms will be possible.

The wind speed data of most studies in this field, were collected or recorded at $10 \mathrm{~m}$ above the ground level. The wind speed data of five coastal locations of the kingdom of Sudia Arabia were collected via meteorological measurement for 14 years, where wind data recorded at $10 \mathrm{~m}$ height of four locations except at one location at $8 \mathrm{~m}$ height above the ground level [1]. The wind speed data for the Waterloo region in Canada for 5 years, four locations in Ethiopia, three locations in southeastern of Nigeria for (25 -37) years, and Ardabil city of Iran for 6 years, were measured at $10 \mathrm{~m}$ above the ground level [2, 3, 6, and 9]. At $700 \mathrm{~m}$ from the sea level of Naxos Island of Greece, the wind speed data were measured via a measurement mast [4]. The NASA Langley research center of Oman, Islamic Republic Iran Meteorological Organization at $10 \mathrm{~m}$, and Meteorological Department Oshodi at $10 \mathrm{~m}$ of Kano in Nigeria, were used to collect the wind speed data in these countries in order to analyze the wind speed data and assess the wind energy potential. In this study, the daily wind speed data were collected at the stations height of selected sites.

The average of wind speed, standard deviation, shape factor, scale factor, most probable wind speed, wind speed carrying maximum energy, wind power density, and wind energy density were achieved by different wind statistical models. The Weibull distribution which is a famous model was used for majority of several studies. The Weibull distribution and Rayleigh distribution was used to analyze wind data and wind energy potential [4]. Several methods were used to estimate the Weibull parameters. Six methods (Probability weighted moments, graphical method, Empirical method, Moment method, Maximum Likelihood method, and Energy Pattern factor method) of Weibull distribution were used to calculate the average of wind speed, standard deviation, shape factor, scale factor, most probable wind speed, wind speed carrying maximum energy, wind power density, and wind energy density [7]. Graphical method [4, and 8] and Empirical method [6, and 9] were used to evaluate Weibull parameters. In some studies, a software tools were used to conclude the Weibull parameters. (HOMER) software tool were used to estimate the shape and scale factors in order to assess wind energy potential and wind speed characteristics [6]. In this study, the Weibull distribution was used to estimate the specified parameters and the accuracy of Weibull distribution was checked. 
The results of previous studies were presented as average of hourly, monthly, and annual for wind speed, shape factor, scale factor, probability density function, cumulative distribution function, duration curve, most probable wind speed, wind speed carrying maximum energy, capacity factor and energy output of wind turbine. According to [3], the three of four locations were reasonable for wind energy potential. A spatial distribution of wind characteristics for whole Oman were provided [5]. The electricity generation from the wind were viable economically at and above $10 \mathrm{~m}$ height [8]. The wind potential is very suitable for off-grid connections and is acceptable for connecting to power grid [9].

\section{SITES INFORMATION AND WIND DATA SOURCE}

The wind data for three selected sites in Iraq were collected from the metrological weather web site of weather underground organization (WUO) [10] as a daily average wind velocity. The elevation, latitude, and longitude of selected stations were $\left(9 \mathrm{~m}, 31.83^{\circ} \mathrm{N}, 47.17^{\circ} \mathrm{E}\right),(5 \mathrm{~m}, 31.02$ $\left.{ }^{\circ} \mathrm{N}, 46.23{ }^{\circ} \mathrm{E}\right),\left(3 \mathrm{~m}, 30.37^{\circ} \mathrm{N}, 48.25^{\circ} \mathrm{E}\right)$ for Amarah, Nasiriyah, and Basrah respectively, Table. 1. The maximum, minimum, and average daily of wind speed are available in (WUO) web site. In present study, the average of daily wind speed was used as input parameter. The collected wind speed data were compared with wind speed data from another web site for verification. The wind speed data from (WUO) web site were significantly identical with the wind speed data of intellicast web site. According to daily average wind velocities, the monthly and annually average wind velocities were estimated at stations heights. Extrapolation of stations elevations has been used to estimate the wind velocities at 60 $\mathrm{m}, 90 \mathrm{~m}$, and $120 \mathrm{~m}$ via wind shear power law.

\section{MATHEMATICAL MODEL}

The daily average of wind velocities are collected from the web site of (WUO). Accordingly, the monthly and annually average of measured wind velocity and Weibull estimated of wind velocity are calculated as [11, PP.64]:

$\overline{\mathrm{V}}=\left\{\left\langle\sum_{\mathrm{i}=1}^{\mathrm{N}} \mathrm{V}_{\mathrm{i}}^{3}\right\rangle / N\right\}^{1 / 3}$

Here $\left(\mathrm{V}_{i}\right)$ is the individual wind velocity collected from (WUO), $(N)$ is the number of collected data, and $(\bar{V})$ is the average of wind velocity $(\mathrm{m} / \mathrm{s})$.

The wind is stochastic quantity. Consequently, the standard deviation is necessary to be estimated, it can be formulated as [11, P.64]:

$\sigma=\sqrt{\sum_{i=1}^{N}\left(\mathrm{~V}_{i}-\overline{\mathrm{V}}\right)^{2} / N}$

Here $(\sigma)$ is the standard deviation $(\mathrm{m} / \mathrm{s})$.

The shape and scale factors of Weibull distribution for wind data analysis can be expressed as [11, PP.75-76):

$k=(\sigma / \overline{\mathrm{V}})^{-1.090}$

$C=\left(\overline{\mathrm{V}} k^{2.6674} /\left(0.184+0.816 k^{2.73855}\right)\right)$

Here $(k)$ is the shape factor (dimensionless), and $(C)$ is the scale factor $(\mathrm{m} / \mathrm{s})$.

The Weibull probability density function $f(V)$ is used to describe wind speed. The integral of the probability density function represent the cumulative distribution $F(V)$. It can be defined as [11, PP.68]:

$\mathrm{f}(\mathrm{V})=[\mathrm{K} / \mathrm{C}][\mathrm{V} / \mathrm{C}]^{\mathrm{K}-1} \mathrm{e}^{-(\mathrm{V} / \mathrm{C})^{\mathrm{K}}}$

$F(V)=\int_{0}^{\infty} f(V) d V=1-e^{-(V / C)^{K}}$

According to Weibull distribution, the average of wind speed, and standard deviation also can be estimated as [11, PP.6971]:

$\overline{\mathrm{V}}=\mathrm{C} \Gamma[1+(1 / \mathrm{k})]$

$\sigma=\mathrm{C}\left\{\Gamma[1+(2 / \mathrm{k})]-\Gamma^{2}[1+(1 / \mathrm{k})]\right\}^{1 / 2}$

Here $(\Gamma)$ is the gamma function.

Several parameters were corrected at stations elevation and selected heights. The air density correction with height have been employed [12, PP.31]:

$\rho=\rho_{o}-\left[1.194 \times 10^{-4} \times H\right]$

Here $(\rho)$ is the air density at any height $\left(\mathrm{kg} / \mathrm{m}^{3}\right),\left(\rho_{o}=\right.$ $\left.1.225 \mathrm{~kg} / \mathrm{m}^{3}\right)$ represent the air standard density at $(T=$ $\left.15^{\circ} \mathrm{C}\right)$ and $(P=1 \mathrm{~atm})$, and $(H)$ is the height in $(\mathrm{m})$.

The change in wind speed with height can be calculated by using wind shear power law as [13, PP.37]:

$V_{2}=V_{1}\left(H_{2} / H_{1}\right)^{\alpha}$

Here $\left(H_{1}\right)$ is the stations elevation in $(\mathrm{m}),\left(H_{2}\right)$ is the selected height in $(\mathrm{m}),\left(V_{1}\right)$ is the wind velocity $(\mathrm{m} / \mathrm{s})$ at stations elevation, $\left(V_{2}\right)$ is the corrected wind velocity $(\mathrm{m} / \mathrm{s})$ at selected height, and $(\alpha)$ is the wind shear exponent.

The wind shear exponent can be formulated as [14, PP. 15]:

$\alpha=\left[0.096 \log _{10}(Z)+0.016\left(\log _{10}(Z)\right)^{2}+0.24\right]$

Here $(Z)$ is the roughness height of terrain in $(m)$.

According to the table of [14, PP.14], the appropriate value of roughness height $(Z)$ for selected sites is $(1.5 \mathrm{~m})$.

Also, the correction of shape and scale factors with selected heights can be modified as [7]:

$k_{H 2}=k_{H 1}\left[1-0.0881 \ln \left(H_{2} / H_{1}\right)\right]^{-1}$
$n=\left[0.37-0.0881 \ln \left(C_{H 1}\right)\right]$
$C_{H 2}=C_{H 1}\left(H_{2} / H_{1}\right)^{n}$

The individual corrected of measured wind power density and energy density at any height can be considered as

$P D_{c i}=(1 / 2) \rho \bar{V}_{i}^{3}$

$E D_{c i}=(1 / 2) \rho \bar{V}_{i}^{3} T$

Here $(T)$ is the time duration.

Accordingly, the total corrected of measured wind power density and wind energy density at any height by using the corrected wind velocities from wind shear power law, can be written as:

$P D_{c t}=\sum_{i=1}^{N}(1 / 2) \rho \bar{V}_{i}^{3} / N$
$E D_{c t}=P D_{c t} T$ 
According to the Weibull distribution, the corrected of estimated wind power density and wind energy density at any height for selected sites, can be expressed as [9]:

$P D_{c W}=(1 / 2) \rho C^{3} \Gamma(1+\langle 3 / k\rangle)$

$E D_{c W}=(1 / 2) \rho C^{3} \Gamma(1+\langle 3 / k\rangle) T$

The most probable wind velocity $V_{m p}(\mathrm{~m} / \mathrm{s})$ and wind velocity carrying maximum energy $V_{m E}(\mathrm{~m} / \mathrm{s})$ in term of shape and scale factors, become [11, PP.82-83]:

$V_{m p}=C[1-(1 / k)]^{1 / k}$

$V_{m E}=C[1+(2 / k)]^{1 / k}$

The accuracy of Weibull distribution in estimating the site's actual parameters with predicted Weibull results, can be check by calculated the determination factor $\left(R^{2}\right)$ and root mean square error (RMSE) as [8] :

$R^{2}=\frac{\sum_{i=1}^{N}\left(y_{i}-z_{i}\right)^{2}-\sum_{i=1}^{N}\left(x_{i}-y_{i}\right)^{2}}{\sum_{i=1}^{N}\left(y_{i}-z_{i}\right)^{2}}$

$$
R M S E=\left[\frac{1}{N} \sum_{i=1}^{N}\left(y_{i}-x_{i}\right)^{2}\right]^{1 / 2}
$$

Here $\left(y_{i}\right),\left(x_{i}\right)$, and $\left(z_{i}\right)$ is the actual data, predicted Weibull results, and mean of actual data respectively.

\section{RESULTS AND DISCUSSION}

Analysis of wind speed data and wind energy potential at three selected sites in Iraq has been investigated in this study. The daily average of wind speed data for Amarah, Nasiriyah, and Basrah over whole 1-year from August 2014 to July 2015 were collected and analyzed. Monthly and annually average of wind velocities, standard deviation, wind power densities, and wind energy densities were estimated according to measured wind velocities. According to the Weibull distribution the monthly and annually average of estimated wind velocities, standard deviation, shape factor, scale factor, most probable wind velocity, wind velocity carrying maximum energy, wind power densities, and wind energy densities were determined. The difference between the Weibull estimated and measured parameters were showed with the blue color on the bars of Figs. $(1,2,8,9,10$, and 11). All the parameters mentioned above listed in Tables. $(\mathbf{2}, \mathbf{3}, \mathbf{4}$, 5 , and 6).

In general, the measured and Weibull estimated monthly and annually average of wind velocities for the same site of selected sites are approximately identical. Fig.1 illustrate the measured and Weibull estimated monthly average of wind velocities for selected sites. While Fig.2 demonstrate the measured and Weibull estimated annual average of wind velocities. The higher and lower of measured and Weibull estimated monthly average of wind velocities were $(6.4643$, and $2.4149 \mathrm{~m} / \mathrm{s})$ and $(6.4704$, and $2.4170 \mathrm{~m} / \mathrm{s})$ at June and November respectively for Amarah, (4.5369, and 2.7567 $\mathrm{m} / \mathrm{s}$ ) and $(4.5374$, and $2.7598 \mathrm{~m} / \mathrm{s}$ ) at May and December respectively for Nasiriyah, and $(5.5146$, and $2.2044 \mathrm{~m} / \mathrm{s})$ and $(5.5181$, and $2.2046 \mathrm{~m} / \mathrm{s}$ ) at June and December respectively for Basrah. From Tables. (2, 3, and 4) the sites have the highest measured and Weibull estimated annual average of wind velocity at stations elevation, were $(4.0138$ and $4.0166 \mathrm{~m} / \mathrm{s}),(3.9241$ and $3.9253 \mathrm{~m} / \mathrm{s}),(3.5707$ and 3.5743 $\mathrm{m} / \mathrm{s}$ ) for Amarah, Basrah, and Nasiriyah respectively.

Fig.3 display the wind velocity profiles for selected sites at selected heights of annual shape and scale factors. Extrapolation of stations elevations were used to estimate the wind velocities at 60,90 , and $120 \mathrm{~m}$ according to the wind shear power law. The wind shear power law is an indication to the change of wind velocity with height. At selected heights, the wind velocities were used to correct the shape and scale factors of Weibull distribution. Also, to estimate the wind power density and wind energy density. From Fig.3 the best velocity profiles were for Basrah, Nasiriyah, and Amarah respectively. The measured and Weibull estimated of wind velocities, wind power density, wind energy density, shape factor, and scale factor are shown in Table.6.

Indeed, the wind velocity carrying maximum energy always more than most probable wind velocity. In the wind energy analysis, the most frequent wind velocity for wind probability distribution is the most probable wind velocity. Fig. 4 show the monthly average of the most probable wind velocity and wind velocity carrying maximum energy for selected sites at stations elevation. The higher and lower of Weibull estimated monthly average of wind velocities carrying maximum energy were $(8.5628$ and $3.2185 \mathrm{~m} / \mathrm{s})$ at June and November respectively for Amarah, $(6.8325$ and $3.5663 \mathrm{~m} / \mathrm{s})$ at May and December respectively for Nasiriyah, and (7.5780 and $3.3528 \mathrm{~m} / \mathrm{s}$ ) at June and December respectively for Basrah. Also, the higher and lower of Weibull estimated monthly average of most probable wind velocities were $(6.3452$ and $2.3594 \mathrm{~m} / \mathrm{s}$ ) at June and November respectively for Amarah, (4.4528 and $2.7507 \mathrm{~m} / \mathrm{s}$ ) at June and December respectively for Nasiriyah, and $(5.2531$ and $1.8805 \mathrm{~m} / \mathrm{s}$ ) at June and December respectively for Basrah. From Tables. (2, 3, and 4), the sites have the highest Weibull estimated annual average of wind velocity carrying maximum energy were (5.4989, 5.0839, and $4.4895 \mathrm{~m} / \mathrm{s}$ ) for Basrah, Amarah, and Nasiriyah respectively. In addition, the sites have the highest Weibull estimated annual average of most probable wind velocity were $(3.5208,3.4652$, and $3.2793 \mathrm{~m} / \mathrm{s}$ ) for Amarah, Nasiriyah, and Basrah respectively.

Fig. 5 show the annual average of wind energy carrying maximum energy and most probable wind velocity for selected sites at selected heights $(60,90$, and $120 \mathrm{~m})$ respectively. From Fig. 5 and Table.5, the higher of the annual average of wind energy carrying maximum energy and most probable wind velocity were for Basrah, Nasiriyah, and Amarah respectively for any of selected heights. The blue colors in Fig. $(4,5)$ of every bar, represent the difference between wind velocity carrying maximum energy and most probable wind velocity.

In fact, the famous distribution which used in wind energy analysis is the Weibull distribution. It is used to describe the wind variations with suitable accuracy. Fig.6 and Fig.7 illustrates the probability density function and cumulative distribution function of selected sites at stations elevation for annual shape and scale factors, in order to characterize the wind velocity variations for the selected sites.

Fig.8 illustrate the monthly average of wind power density at stations elevation of selected sites. The higher and lower of measured monthly average of wind power densities were (165.3063 and $8.6183 \mathrm{~W} / \mathrm{m}^{2}$ ) at June and November respectively for Amarah, (57.1705 and $12.8252 \mathrm{~W} / \mathrm{m}^{2}$ ) at May and December respectively for Nasiriyah, and (102.6883 and $6.5592 \mathrm{~W} / \mathrm{m}^{2}$ ) at June and December respectively for Basrah. Also, the higher and lower of Weibull estimated monthly average of wind power densities were (231.5886 and $12.1919 \mathrm{~W} / \mathrm{m}^{2}$ ) at June and November respectively for Amarah, (98.8831 and $17.3148 \mathrm{~W} / \mathrm{m}^{2}$ ) at May and December respectively for Nasiriyah, and (152.5685 and 
$11.5366 \mathrm{~W} / \mathrm{m}^{2}$ ) at June and December respectively for Basrah. From table (2, 3, and 4), the sites have the highest measured annual average of wind power densities at stations elevation were $\left(39.5725,36.9985\right.$, and $\left.27.8722 \mathrm{~W} / \mathrm{m}^{2}\right)$ for Amarah, Basrah, and Nasiriyah respectively. Also, the sites have the highest Weibull estimated annual average of wind power densities at stations elevation were $(52.3616,45.5274$ and $33.8317 \mathrm{~W} / \mathrm{m}^{2}$ ) for Basrah, Amarah, and Nasiriyah respectively.

Fig.9 state the measured and Weibull estimated annual average of wind power densities for selected stations at selected heights $(60,90$, and $120 \mathrm{~m})$. The measured annual average of wind power densities were $(170.0043,231.7114$, and $\left.288.3992 \mathrm{~W} / \mathrm{m}^{2}\right),(188.3153,256.6677$, and $319.4584 \mathrm{~W} / \mathrm{m}^{2}$ ), and $(370.5608,505.0603$, and 628.6229 $\left.W / \mathrm{m}^{2}\right)$ for Amarah, Nasiriyah, and Basrah at $(60,90$, and $120 \mathrm{~m})$ respectively. Also, the Weibull estimated annual average of wind power densities were $(166.4422,219.9666$, and $\left.268.0718 \mathrm{~W} / \mathrm{m}^{2}\right),(206.3821,277.4621, \quad$ and $342.1760 \mathrm{~W} / \mathrm{m}^{2}$ ), and $(386.6496,508.9844$, and 618.6966 $\left.W / \mathrm{m}^{2}\right)$ for Amarah, Nasiriyah, and Basrah at $(60,90$, and $120 \mathrm{~m}$ ) respectively. Obviously, from Fig. 9 and Table. 6 the best annual average of wind power density were for Basrah, Nasiriyah, and Amarah respectively.

The assessment classification for the wind resource as [9]:

$\begin{array}{lc}\text { Fair } & \left(\boldsymbol{P}_{\boldsymbol{D}}<100 \mathrm{~W} / \boldsymbol{m}^{2}\right) \\ \text { Fairly good } & \left(100 \leq P_{D} \leq 300 \mathrm{~W} / \mathrm{m}^{2}\right) \\ \text { Good } & \left(300 \leq P_{D}<700 \mathrm{~W} / \mathrm{m}^{2}\right) \\ \text { Very good } & \left(P_{D} \geq 700 \mathrm{~W} / \mathrm{m}^{2}\right)\end{array}$

So, the wind classes according to the above classification for the selected sites was tabulated in Table. 7.

Fig.10 clarify the monthly average of wind energy density at stations elevation of selected sites. The higher and lower of measured wind energy densities were (119.02 and 06.21 $k W h / m^{2}$ ) at June and November respectively for Amarah, (42.535 and $09.542 \mathrm{kWh} / \mathrm{m}^{2}$ ) at May and December respectively for Nasiriyah, and (73.936 and $\left.04.880 \mathrm{kWh} / \mathrm{m}^{2}\right)$ at June and December respectively for Basrah. Also, the higher and lower of Weibull estimated energy of power densities were $\left(166.74\right.$ and $\left.08.78 \mathrm{kWh} / \mathrm{m}^{2}\right)$ at June and November respectively for Amarah, (73.569 and 12.882 $\mathrm{kWh} / \mathrm{m}^{2}$ ) at May and December respectively for Nasiriyah, and $\left(109.85\right.$ and $\left.08.58 \mathrm{kWh} / \mathrm{m}^{2}\right)$ at June and December respectively for Basrah. From Tables. (2, 3, and 4), the sites have the highest measured annual average of wind energy densities at selected stations elevation were (345.41, 322.08, and $244.41 \mathrm{kWh} / \mathrm{m}^{2}$ ) for Amarah, Basrah, and Nasiriyah respectively. Also, the sites have the highest Weibull estimated annual average of wind energy densities at selected stations elevation were $(530.52,511.08$, and 335.38 $\mathrm{kWh} / \mathrm{m}^{2}$ )for Basrah, Amarah, and Nasiriyah respectively.

Fig.11 show the annual average for measured and Weibull estimated of wind energy densities of selected stations at selected heights $(60,90$, and $120 \mathrm{~m})$. The annual average of measured wind energy densities were $(1483.9,2022.5$, and $\left.2517.3 \mathrm{kWh} / \mathrm{m}^{2}\right),\left(1615.5,2251.0\right.$, and $\left.2801.7 \mathrm{kWh} / \mathrm{m}^{2}\right)$, and $\left(3225.8,4396.7\right.$, and $5472.3 \mathrm{kWh} / \mathrm{m}^{2}$ ) for Amarah,
Nasiriyah, and Basrah at $(60,90$, and $120 \mathrm{~m})$ respectively. Also, the annual average of Weibull estimated wind energy densities were $\left(1727.8,2249.7\right.$, and $\left.2714.1 \mathrm{kWh} / \mathrm{m}^{2}\right)$, (1935.7, 2583.6, and $\left.3170.8 \mathrm{kWh} / \mathrm{m}^{2}\right)$, and (3688.6, 4820.3, and $5829.8 \mathrm{kWh} / \mathrm{m}^{2}$ ) for Amarah, Nasiriyah, and Basrah at $(60,90$, and $120 \mathrm{~m})$ respectively. Obviously, from Fig. 11 and Table. 6 the best annual average of wind energy density were for Basrah, Nasiriyah, and Amarah respectively.

\section{CONCLUSIONS}

The results of the present study lead to the following conclusions:

1. The annual average for measured and Weibull estimated of wind velocities at stations elevation were $(4.0138,3.5707$, and $3.9241 \mathrm{~m} / \mathrm{s})$ and $(4.0166,3.5743$, and $3.9253 \mathrm{~m} / \mathrm{s}$ ) for Amarah, Nasiriyah, and Basrah respectively.

2. The Weibull estimated annual average of shape and scale factors at stations elevation were (2.7901, 3.5023, and 2.3279) and (4.1590, 3.8779, 4.1943 $\mathrm{m} / \mathrm{s}$ ) for Amarah, Nasiriyah, and Basrah respectively.

3. The annual average of wind velocity carrying maximum energy and most probable wind velocities at stations elevation were $(5.0839,4.4895$, and $5.4989 \mathrm{~m} / \mathrm{s}$ ) and $(3.5208,3.4652$, and 3.2793 $\mathrm{m} / \mathrm{s}$ ) for Amarah, Nasiriyah, and Basrah respectively.

4. The annual average for measured and Weibull estimated of wind power densities at stations elevation were $(39.5725,27.8722$, and 36.9985 $\left.\mathrm{W} / \mathrm{m}^{2}\right)$ and $(45.5274,33.8317$, and 52.3616 $W / m^{2}$ ) for Amarah, Nasiriyah, and Basrah respectively.

5. The annual average for measured and Weibull estimated of wind energy densities at stations elevation were $(345.41,244.44$, and 322.08 $\left.\mathrm{kWh} / \mathrm{m}^{2}\right)$ and $(511.08,335.38$, and 530.52 $\mathrm{kWh} / \mathrm{m}^{2}$ ) for Amarah, Nasiriyah, and Basrah respectively.

6. From the annual average of wind power densities at stations elevation, It is worth mentioning that the selected sites are suitable for off-grid applications in remote and populated areas such as pumping water, batteries charging, lightening of streets, and domestic applications.

7. The wind classes for selected sites were fair at stations elevation. While the wind classes were fairly good at $(60,90,120 \mathrm{~m})$ for Amarah, fairly good at $(60$, and $90 \mathrm{~m})$ but it were good at $120 \mathrm{~m}$ for Nasiriyah. While, it were good at selected heights for Basrah. So, Basrah is acceptable for connecting to power grid and Nasiriyah at height $120 \mathrm{~m}$.

8. According to the values of determination factor and root mean square error in Table.6, the statistical model of Weibull distribution have a good accuracy in estimating the site's actual data. 
Table 1. Elevations of different stations in Iraq.

\begin{tabular}{|c|c|c|c|c|c|}
\hline No. & Stations & Elevation (m) & Latitude & Longitude & Location in Iraq \\
\hline 1 & Amarah & 9 & $31.83^{\circ} \mathrm{N}$ & $47.17^{\circ} \mathrm{E}$ & South-eastern Iraq \\
\hline 2 & Nasiriyah & 5 & $31.02^{\circ} \mathrm{N}$ & $46.23^{\circ} \mathrm{E}$ & Southeast Iraq \\
\hline 3 & Basrah & 3 & $30.37^{\circ} \mathrm{N}$ & $48.25^{\circ} \mathrm{E}$ & South of Iraq \\
\hline
\end{tabular}

Table 2. Measured and Weibull estimated parameters of Amarah at station elevation.

\begin{tabular}{|c|c|c|c|c|c|c|c|c|c|c|c|c|c|c|c|}
\hline \multirow[b]{2}{*}{$\hat{\mathbf{g}}$} & \multirow[b]{2}{*}{ Year } & \multirow[b]{2}{*}{ Month } & \multicolumn{4}{|c|}{ Parameters of measured quantities } & \multicolumn{8}{|c|}{ Estimated Parameters by Weibull Distribution } & \multirow{2}{*}{$\begin{array}{c}\text { Annual } \\
\text { parameters }\end{array}$} \\
\hline & & & $\begin{array}{c}\bar{V} \\
(\mathrm{~m} / \mathrm{s})\end{array}$ & $\begin{array}{c}\sigma \\
(\mathrm{m} / \mathrm{s})\end{array}$ & $\begin{array}{c}\mathrm{PD} \\
\left(\mathrm{W} / \mathrm{m}^{2}\right)\end{array}$ & $\begin{array}{c}\text { ED } \\
\left(\mathrm{kWh} / \mathrm{m}^{2}\right)\end{array}$ & $\begin{array}{l}\mathrm{K} \\
(-)\end{array}$ & $\begin{array}{c}\mathrm{C} \\
(\mathrm{m} / \mathrm{s})\end{array}$ & $\begin{array}{c}\bar{V} \\
(\mathrm{~m} / \mathrm{s})\end{array}$ & $\begin{array}{c}\sigma \\
(\mathrm{m} / \mathrm{s})\end{array}$ & $\begin{array}{l}V_{m B} \\
(\mathrm{~m} / \mathrm{s})\end{array}$ & $\begin{array}{l}V_{m p} \\
(\mathrm{~m} / \mathrm{s})\end{array}$ & $\begin{array}{c}\mathrm{PD} \\
\left(\mathrm{W} / \mathrm{m}^{2}\right)\end{array}$ & $\begin{array}{c}\text { ED } \\
\left(\mathrm{kWh} / \mathrm{m}^{2}\right)\end{array}$ & \\
\hline \multirow{5}{*}{\multicolumn{2}{|c|}{ 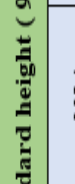 }} & Aug. & 3.7517 & 1.6865 & 32.3154 & 24.04 & 2.3905 & 4.2334 & 3.7526 & 1.6714 & 5.4593 & 3.3748 & 52.7548 & 39.25 & \multirow{6}{*}{ 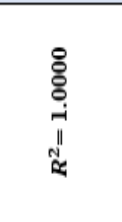 } \\
\hline & & Sep. & 3.6659 & 1.3666 & 30.1486 & 21.71 & 2.9317 & 4.1128 & 3.6690 & 1.3613 & 4.9112 & 3.5673 & 43.0022 & 30.96 & \\
\hline & & Oct. & 3.3782 & 1.2827 & 23.5929 & 17.55 & 2.8735 & 3.7930 & 3.3809 & 1.2771 & 4.5585 & 3.2684 & 34.0428 & 25.33 & \\
\hline & & Nov. & 2.4149 & 0.8881 & 8.6183 & 06.21 & 2.9751 & 2.7077 & 2.4170 & 0.8850 & 3.2185 & 2.3594 & 12.1919 & 08.78 & \\
\hline & & Dec. & 2.4871 & 0.9829 & 9.4147 & 07.00 & 2.7508 & 2.7967 & 2.4887 & 0.9776 & 3.4113 & 2.3731 & 13.9452 & 10.38 & \\
\hline & \multirow{7}{*}{ 党 } & Jan. & 3.0990 & 1.3702 & 18.2133 & 13.55 & 2.4341 & 3.4959 & 3.0999 & 1.3586 & 4.4727 & 2.8130 & 29.3303 & 21.82 & \\
\hline$=$ & & Feb. & 3.2752 & 1.1549 & 21.5000 & 14.45 & 3.1150 & 3.6652 & 3.2785 & 1.1521 & 4.2978 & 3.2368 & 29.6778 & 19.94 & \multirow{7}{*}{ 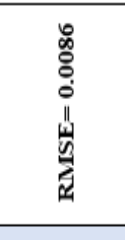 } \\
\hline$\approx$ & & Mar. & 2.9744 & 1.1937 & 16.1036 & 11.98 & 2.7053 & 3.3465 & 2.9762 & 1.1867 & 4.1062 & 2.8217 & 24.1060 & 17.93 & \\
\hline$\overline{3}$ & & Apr. & 4.6213 & 1.9729 & 60.3973 & $\begin{array}{l}43.49 \\
\end{array}$ & 2.5289 & 5.2090 & 4.6231 & 1.9580 & 6.5588 & 4.2691 & 94.5962 & 68.11 & \\
\hline 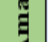 & & May. & 3.7781 & 1.2284 & 33.0024 & 24.55 & 3.4028 & 4.2105 & 3.7828 & 1.2278 & 4.8232 & 3.8012 & 43.6520 & 32.48 & \\
\hline & & Jun. & 6.4643 & 2.3389 & 165.3063 & 119.02 & 3.0287 & 7.2428 & 6.4704 & 2.3317 & 8.5628 & 6.3452 & 231.5886 & 166.74 & \\
\hline & & Jul. & 4.5132 & 2.0648 & 56.2573 & 41.86 & 2.3451 & 5.0941 & 4.5141 & 2.0455 & 6.6265 & 4.0191 & 93.2262 & 69.36 & \\
\hline \multicolumn{3}{|c|}{ Annual Average } & 4.0138 & 1.4609 & 39.5725 & 345.41 & 2.7901 & 4.1590 & 4.0166 & 1.4527 & 5.0839 & 3.5208 & 45.5274 & 511.08 & \\
\hline
\end{tabular}

Table 3. Measured and Weibull estimated parameters of Nasiriyah at station elevation.

\begin{tabular}{|c|c|c|c|c|c|c|c|c|c|c|c|c|c|c|c|}
\hline \multirow{14}{*}{ 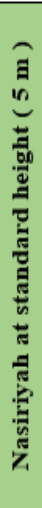 } & \multirow[b]{2}{*}{ Year } & \multirow[b]{2}{*}{ Month } & \multicolumn{4}{|c|}{ Parameters of measured quantities } & \multicolumn{8}{|c|}{ Estimated Parameters by Weibull Distribution } & \multirow{2}{*}{$\begin{array}{c}\text { Annual } \\
\text { parameters }\end{array}$} \\
\hline & & & $\begin{array}{c}\bar{V} \\
(\mathrm{~m} / \mathrm{s})\end{array}$ & $\begin{array}{c}\sigma \\
(\mathrm{m} / \mathrm{s})\end{array}$ & $\begin{array}{c}\mathrm{PD} \\
\left(\mathrm{W} / \mathrm{m}^{2}\right)\end{array}$ & $\begin{array}{c}\text { ED } \\
\left(\mathrm{kWh} / \mathrm{m}^{2}\right)\end{array}$ & $\begin{array}{l}\mathrm{K} \\
(-)\end{array}$ & $\begin{array}{c}\mathrm{C} \\
(\mathrm{m} / \mathrm{s})\end{array}$ & $\begin{array}{c}\overline{\bar{V}} \\
(\mathrm{~m} / \mathrm{s})\end{array}$ & $\begin{array}{c}\sigma \\
(\mathrm{m} / \mathrm{s})\end{array}$ & $\begin{array}{l}V_{m E} \\
(\mathrm{~m} / \mathrm{s})\end{array}$ & $\begin{array}{c}V_{m p} \\
(\mathrm{~m} / \mathrm{s})\end{array}$ & $\begin{array}{c}\mathrm{PD} \\
\left(\mathrm{W} / \mathrm{m}^{2}\right)\end{array}$ & $\begin{array}{c}\mathrm{ED} \\
\left(\mathrm{kWh} / \mathrm{m}^{2}\right)\end{array}$ & \\
\hline & \multirow{5}{*}{$\underset{\overline{7}}{\overline{7}}$} & Aug. & 3.6666 & 1.1087 & 30.1776 & 22.452 & 3.6831 & 4.0695 & 3.6716 & 1.1097 & 4.5781 & 3.7341 & 38.5903 & 28.711 & \multirow{6}{*}{ 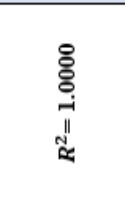 } \\
\hline & & Sep. & 3.2956 & 0.7416 & 21.9128 & 15.777 & 5.0821 & 3.5881 & 3.2976 & 0.7442 & 3.8302 & 3.4367 & 25.2393 & 18.172 & \\
\hline & & Oct. & 3.4156 & 1.2542 & 24.3947 & 18.150 & 2.9802 & 3.8294 & 3.4186 & 1.2499 & 4.5495 & 3.3386 & 34.4757 & 25.650 & \\
\hline & & Nov. & 3.0678 & 1.1119 & 17.6757 & 12.726 & 3.0230 & 3.4375 & 3.0707 & 1.1084 & 4.0662 & 3.0098 & 24.7876 & 17.847 & \\
\hline & & Dec. & 2.7567 & 0.9332 & 12.8252 & 9.542 & 3.2565 & 3.0787 & 2.7598 & 0.9319 & 3.5663 & 2.7507 & 17.3148 & 12.882 & \\
\hline & \multirow{7}{*}{ 党 } & Jan. & 2.8797 & 0.9020 & 14.6196 & 10.877 & 3.5442 & 3.2026 & 2.8835 & 0.9022 & 3.6335 & 2.9166 & 18.9943 & 14.132 & \\
\hline & & Feb. & 3.1787 & 0.9956 & 19.6627 & 13.213 & 3.5444 & 3.5351 & 3.1828 & 0.9959 & 4.0107 & 3.2195 & 25.5454 & 17.167 & \multirow{6}{*}{ 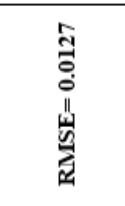 } \\
\hline & & Mar. & 2.9722 & 0.8699 & 16.0742 & 11.959 & 3.8165 & 3.2924 & 2.9764 & 0.8712 & 3.6768 & 3.0405 & 20.2706 & 15.081 & \\
\hline & & Apr. & 3.8678 & 1.2753 & 35.4231 & 25.505 & 3.3513 & 4.3136 & 3.8724 & 1.2743 & 4.9601 & 3.8808 & 47.1781 & 33.968 & \\
\hline & & May. & 4.5369 & 2.1771 & 57.1705 & 42.535 & 2.2262 & 5.1231 & 4.5374 & 2.1541 & 6.8325 & 3.9192 & 98.8831 & 73.569 & \\
\hline & & Jun. & 4.3204 & 1.1819 & 49.3704 & 35.547 & 4.1078 & 4.7657 & 4.3263 & 1.1848 & 5.2489 & 4.4528 & 60.6134 & 43.642 & \\
\hline & & Jul. & 3.8582 & 1.2513 & 35.1600 & 26.159 & 3.4124 & 4.2992 & 3.8630 & 1.2507 & 4.9214 & 3.8837 & 46.4479 & 34.557 & \\
\hline \multicolumn{3}{|c|}{ Annual Average } & 3.5707 & 1.1502 & 27.8722 & 244.44 & 3.5023 & 3.8779 & 3.5743 & 1.1481 & 4.4895 & 3.4652 & 33.8317 & 335.38 & \\
\hline
\end{tabular}

Table 4. Measured and Weibull estimated parameters of Basrah at station elevation.

\begin{tabular}{|c|c|c|c|c|c|c|c|c|c|c|c|c|c|c|c|}
\hline \multirow{14}{*}{ 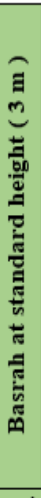 } & \multirow[b]{2}{*}{ Year } & \multirow[b]{2}{*}{ Month } & \multicolumn{4}{|c|}{ Parameters of measured quantities } & \multicolumn{8}{|c|}{ Estimated Parameters by Weibull Distribution } & \multirow{2}{*}{$\begin{array}{c}\text { Annual } \\
\text { parameters }\end{array}$} \\
\hline & & & $\begin{array}{c}\bar{V} \\
(\mathrm{~m} / \mathrm{s})\end{array}$ & $\begin{array}{c}\sigma \\
(\mathrm{m} / \mathrm{s})\end{array}$ & $\begin{array}{c}\mathrm{PD} \\
\left(\mathrm{W} / \mathrm{m}^{2}\right)\end{array}$ & $\begin{array}{c}\text { ED } \\
\left(\mathrm{kWh} / \mathrm{m}^{2}\right)\end{array}$ & $\begin{array}{l}\mathrm{K} \\
(-)\end{array}$ & $\begin{array}{c}\mathrm{C} \\
(\mathrm{m} / \mathrm{s})\end{array}$ & $\begin{array}{c}\bar{V} \\
(\mathrm{~m} / \mathrm{s})\end{array}$ & $\begin{array}{c}\sigma \\
(\mathrm{m} / \mathrm{s})\end{array}$ & $\begin{array}{l}V_{m E} \\
(\mathrm{~m} / \mathrm{s})\end{array}$ & $\begin{array}{c}V_{m p} \\
(\mathrm{~m} / \mathrm{s})\end{array}$ & $\begin{array}{c}\mathrm{PD} \\
\left(\mathrm{W} / \mathrm{m}^{2}\right)\end{array}$ & $\begin{array}{c}\text { ED } \\
\left(\mathrm{kWh} / \mathrm{m}^{2}\right)\end{array}$ & \\
\hline & \multirow{5}{*}{ 离 } & Aug. & 4.1749 & 1.8364 & 44.5571 & 33.151 & 2.4478 & 4.7091 & 4.1762 & 1.8211 & 6.0102 & 3.7998 & 71.4540 & 53.16 & \multirow{6}{*}{ 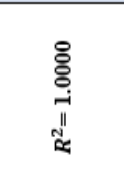 } \\
\hline & & Sep. & 3.8511 & 1.8415 & 34.9730 & 25.181 & 2.2349 & 4.3486 & 3.8515 & 1.8222 & 5.7884 & 3.3349 & 60.2885 & 43.41 & \\
\hline & & Oct. & 3.3378 & 1.5565 & 22.7698 & 16.941 & 2.2968 & 3.7683 & 3.3383 & 1.5412 & 4.9497 & 2.9381 & 38.3699 & 28.55 & \\
\hline & & Nov. & 2.5635 & 1.2482 & 10.3152 & 07.427 & 2.1911 & 2.8949 & 2.5637 & 1.2346 & 3.8920 & 2.1919 & 18.0895 & 13.02 & \\
\hline & & Dec. & 2.2044 & 1.0768 & 6.5592 & 04.880 & 2.1835 & 2.4893 & 2.2046 & 1.0650 & 3.3528 & 1.8805 & 11.5366 & 08.58 & \\
\hline & \multirow{7}{*}{ 告 } & Jan. & 3.0682 & 1.6553 & 17.6860 & 13.158 & 1.9594 & 3.4606 & 3.0682 & 1.6337 & 4.9553 & 2.4037 & 34.4876 & 25.66 & \\
\hline & & Feb. & 4.2522 & 2.0752 & 47.0782 & 31.637 & 2.1857 & 4.8018 & 4.2526 & 2.0525 & 6.4641 & 3.6298 & 82.7324 & 55.60 & \multirow{6}{*}{ 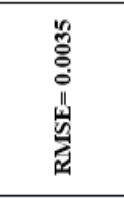 } \\
\hline & & Mar. & 3.2939 & 1.7257 & 21.8832 & 16.281 & 2.0230 & 3.7175 & 3.2939 & 1.7041 & 5.2219 & 2.6539 & 41.3230 & 30.74 & \\
\hline & & Apr. & 4.4543 & 1.7655 & 54.1150 & 38.963 & 2.7421 & 5.0093 & 4.4571 & 1.7558 & 6.1170 & 4.2455 & 80.3146 & 57.83 & \\
\hline & & May. & 3.3716 & 1.2938 & 23.4686 & 17.461 & 2.8405 & 3.7871 & 3.3741 & 1.2878 & 4.5689 & 3.2506 & 34.0915 & 25.36 & \\
\hline & & Jun. & 5.5146 & 2.1892 & 102.6883 & 73.936 & 2.7375 & 6.2021 & 5.5181 & 2.1770 & 7.5780 & 5.2531 & 152.5685 & 109.85 & \\
\hline & & Jul. & 4.5555 & 2.3144 & $\mathbf{5 7 . 8 8 7 8}$ & 43.069 & 2.0921 & 5.1435 & 4.5557 & 2.2869 & 7.0881 & 3.7697 & 105.8511 & 78.75 & \\
\hline \multicolumn{3}{|c|}{ Annual Average } & 3.9241 & 1.7149 & 36.9985 & 322.08 & 2.3279 & 4.1943 & 3.9253 & 1.6985 & 5.4989 & 3.2793 & 52.3616 & 530.52 & \\
\hline
\end{tabular}


Table 5. Annual average of wind velocity carrying maximum energy and most probable wind velocity of selected sites.

\begin{tabular}{|c|c|c|c|}
\hline \multirow{2}{*}{ Selected sits } & Selected height $(\mathbf{m})$ & $\begin{array}{c}\text { wind velocity carrying } \\
\text { maximum energy }(\mathbf{m} / \mathbf{s})\end{array}$ & $\begin{array}{c}\text { most probable wind } \\
\text { velocity }(\mathbf{m} / \mathbf{s})\end{array}$ \\
\hline \multirow{3}{*}{ Amarah } & 60 & 7.9514 & 6.7328 \\
\cline { 2 - 4 } & 90 & 8.8247 & 7.4722 \\
\cline { 2 - 4 } & 120 & 9.5019 & 8.0456 \\
\hline \multirow{3}{*}{ Nasiriyah } & 60 & 7.3882 & 7.0350 \\
\cline { 2 - 4 } & 90 & 8.1996 & 7.8076 \\
\cline { 2 - 4 } & 120 & 8.8288 & 8.4068 \\
\hline \multirow{3}{*}{ Basrah } & 60 & 9.9136 & 8.8275 \\
\cline { 2 - 4 } & 90 & 11.0023 & 9.7970 \\
\cline { 2 - 4 } & 120 & 11.8466 & 10.5488 \\
\hline
\end{tabular}

Table 6. Corrected annual parameters at selected heights of selected sites.

\begin{tabular}{|c|c|c|c|c|c|c|c|c|c|c|c|}
\hline \multirow[b]{2}{*}{ 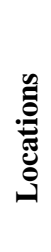 } & \multirow[b]{2}{*}{$\begin{array}{l}\text { Height } \\
\text { (m) }\end{array}$} & \multicolumn{3}{|c|}{$\begin{array}{c}\text { Parameters of measured } \\
\text { quantities }\end{array}$} & \multicolumn{5}{|c|}{ Estimated Parameters by Weibull Distribution } & \multicolumn{2}{|c|}{ Fit goodness } \\
\hline & & $\begin{array}{c}\overline{\boldsymbol{V}} \\
(\mathbf{m} / \mathbf{s})\end{array}$ & $\begin{array}{c}\text { PD } \\
\left(\mathrm{W} / \mathrm{m}^{2}\right)\end{array}$ & $\begin{array}{c}\text { ED } \\
(\mathbf{k W h} / \\
\left.\mathbf{m}^{2}\right)\end{array}$ & $\begin{array}{l}\mathbf{K} \\
(-)\end{array}$ & $\begin{array}{c}\mathbf{C} \\
(\mathbf{m} / \mathbf{s})\end{array}$ & $\begin{array}{c}\overline{\bar{V}} \\
(\mathrm{~m} / \mathbf{s})\end{array}$ & $\begin{array}{c}\text { PD } \\
\left(\mathrm{W} / \mathbf{m}^{2}\right)\end{array}$ & $\begin{array}{c}\text { ED } \\
(\mathbf{k W h} / \\
\left.\mathbf{m}^{2}\right)\end{array}$ & $R^{2}$ & RMSE \\
\hline \multirow{3}{*}{ 宽 } & 60 & 6.5358 & 170.0043 & 1483.9 & 3.3500 & 6.5782 & 6.2405 & 166.4422 & 1727.8 & 0.9594 & 0.4251 \\
\hline & 90 & 7.2536 & 231.7114 & 2022.5 & 3.5002 & 7.2575 & 6.8667 & 219.9666 & 2249.7 & 0.9415 & 0.5563 \\
\hline & 120 & 7.8103 & 288.3992 & 2517.3 & 3.6151 & 7.7821 & 7.3511 & 268.0718 & 2714.1 & 0.9272 & 0.6589 \\
\hline \multirow{3}{*}{ 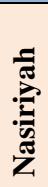 } & 60 & 6.7625 & 188.3153 & 1651.5 & 4.4839 & 7.2131 & 6.6687 & 206.3821 & 1935.7 & 0.9433 & 0.0907 \\
\hline & 90 & 7.5052 & 256.6677 & 2251.0 & 4.6988 & 7.9827 & 7.3897 & 277.4621 & 2583.6 & 0.9243 & 0.1058 \\
\hline & 120 & 8.0812 & 319.4584 & 2801.7 & 4.8642 & 8.5782 & 7.9491 & 342.1760 & 3170.8 & 0.9094 & 0.1149 \\
\hline \multirow{3}{*}{ 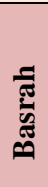 } & 60 & 8.4742 & 370.5608 & 3225.8 & 3.1625 & 8.6551 & 7.9951 & 386.6496 & 3688.6 & 0.9068 & 0.9767 \\
\hline & 90 & 9.4049 & 505.0603 & 4396.7 & 3.3238 & 9.5496 & 8.8185 & 508.9844 & 4820.3 & 0.8826 & 1.1882 \\
\hline & 120 & 10.1266 & 628.6229 & 5472.3 & 3.4486 & 10.2402 & 9.4562 & 618.6966 & 5829.8 & 0.8641 & 1.3522 \\
\hline
\end{tabular}

Table 7. Wind classes of selected sites at station elevation and selected heights.

\begin{tabular}{|c|c|c|c|c|}
\hline \multirow{2}{*}{ Selected Sites } & \multirow{2}{*}{$\begin{array}{c}\text { Wind Classes at } \\
\text { Stations height }\end{array}$} & \multicolumn{3}{|c|}{ Wind Classes at different heights } \\
\cline { 3 - 5 } & & $(60 \mathrm{~m})$ & $(90 \mathrm{~m})$ & $(120 \mathrm{~m})$ \\
\cline { 3 - 5 } & Fair & Fairly good & Fairly good & Fairly good \\
\hline Amarah & Fair & Fairly good & Fairly good & Good \\
\hline Nasiriyah & Fair & Good & Good & Good \\
\hline Basrah & & &
\end{tabular}




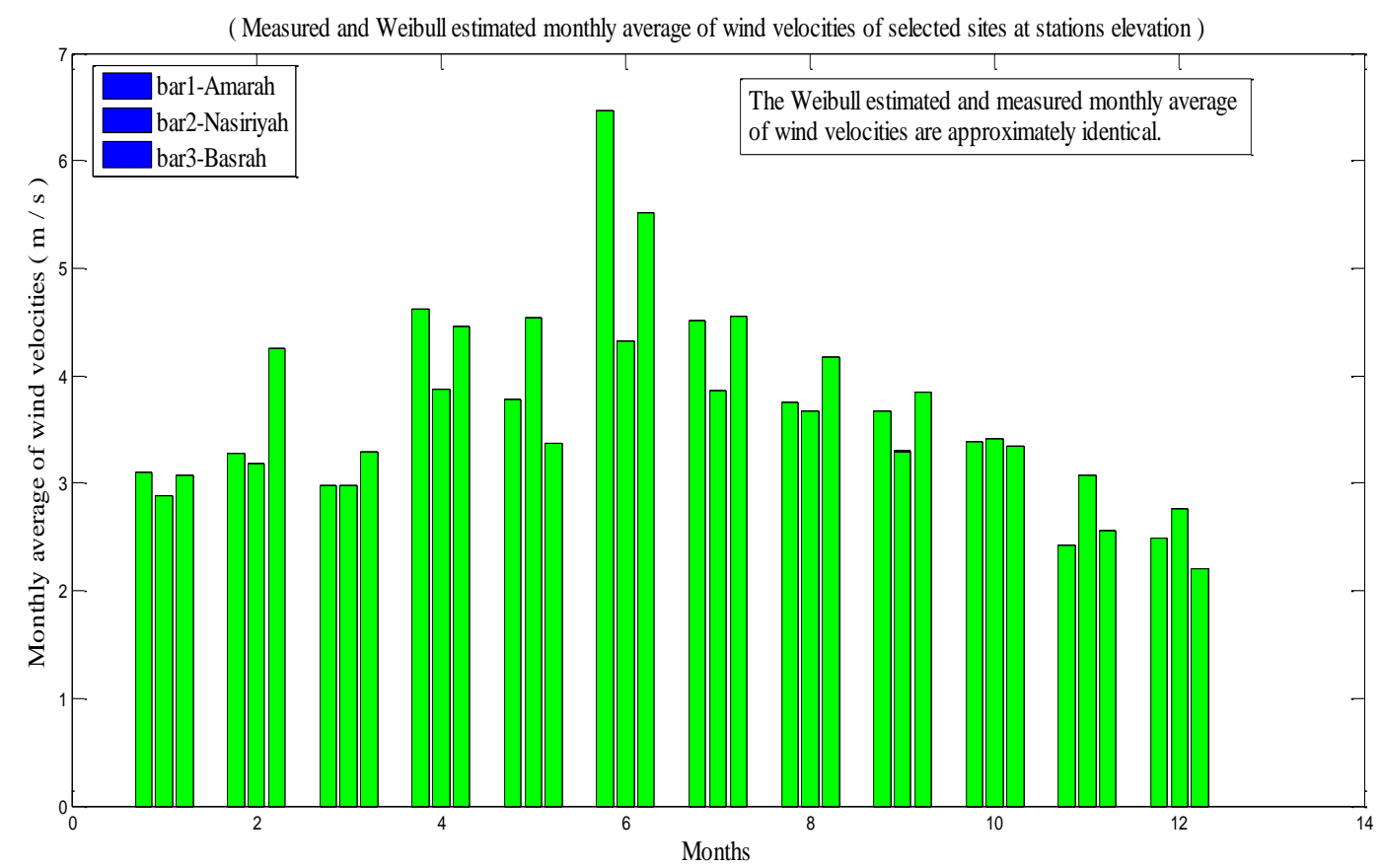

Fig 1: Monthly average of wind velocity of selected sites at stations elevation.

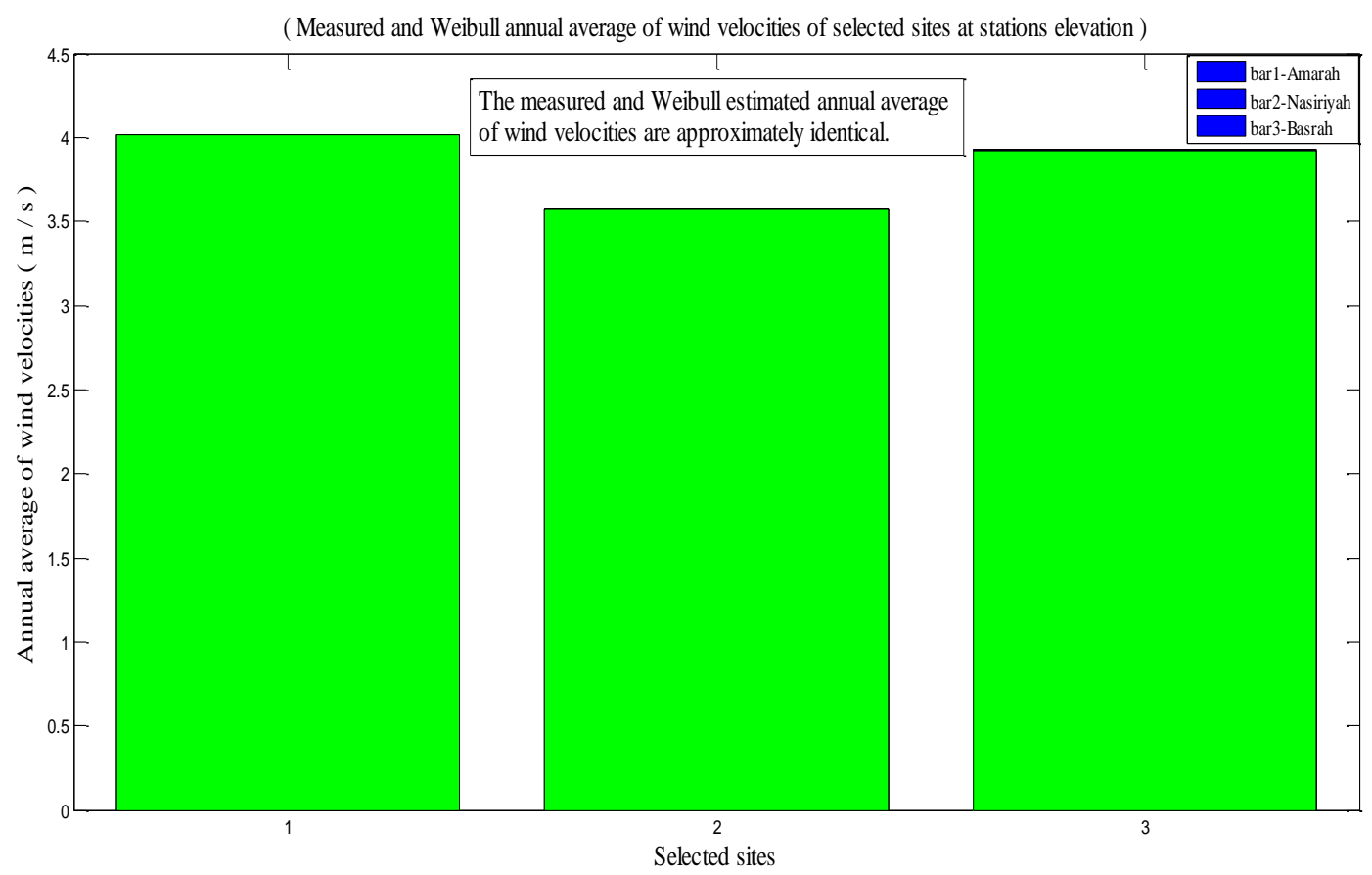

Fig 2: Annual average of wind velocity of selected sites at stations elevation. 
(Wind shear of selected sites at selected heights for annaul average of wind velocities )

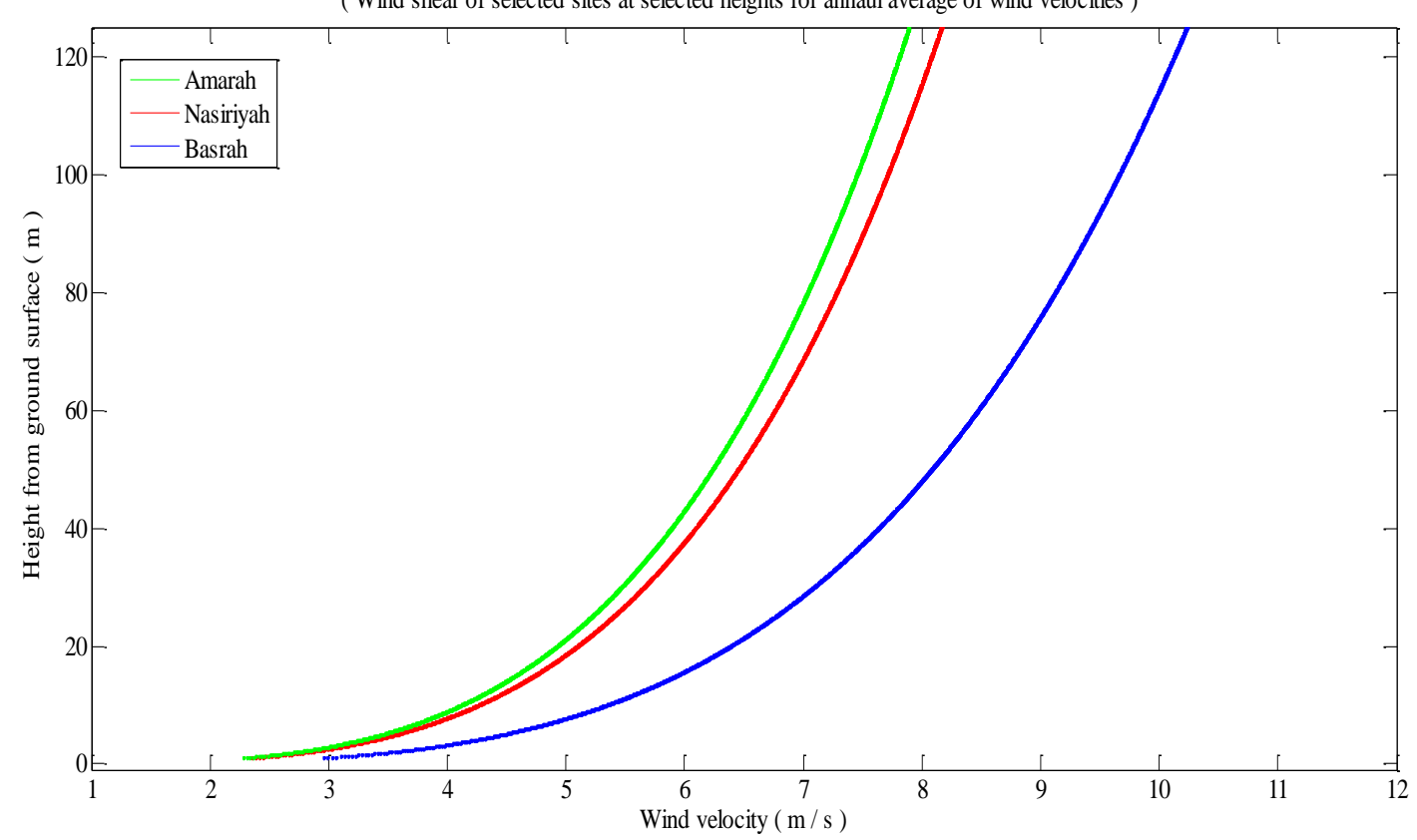

Fig 3: Wind shear of selected sites at selected heights for annual average of wind velocities.

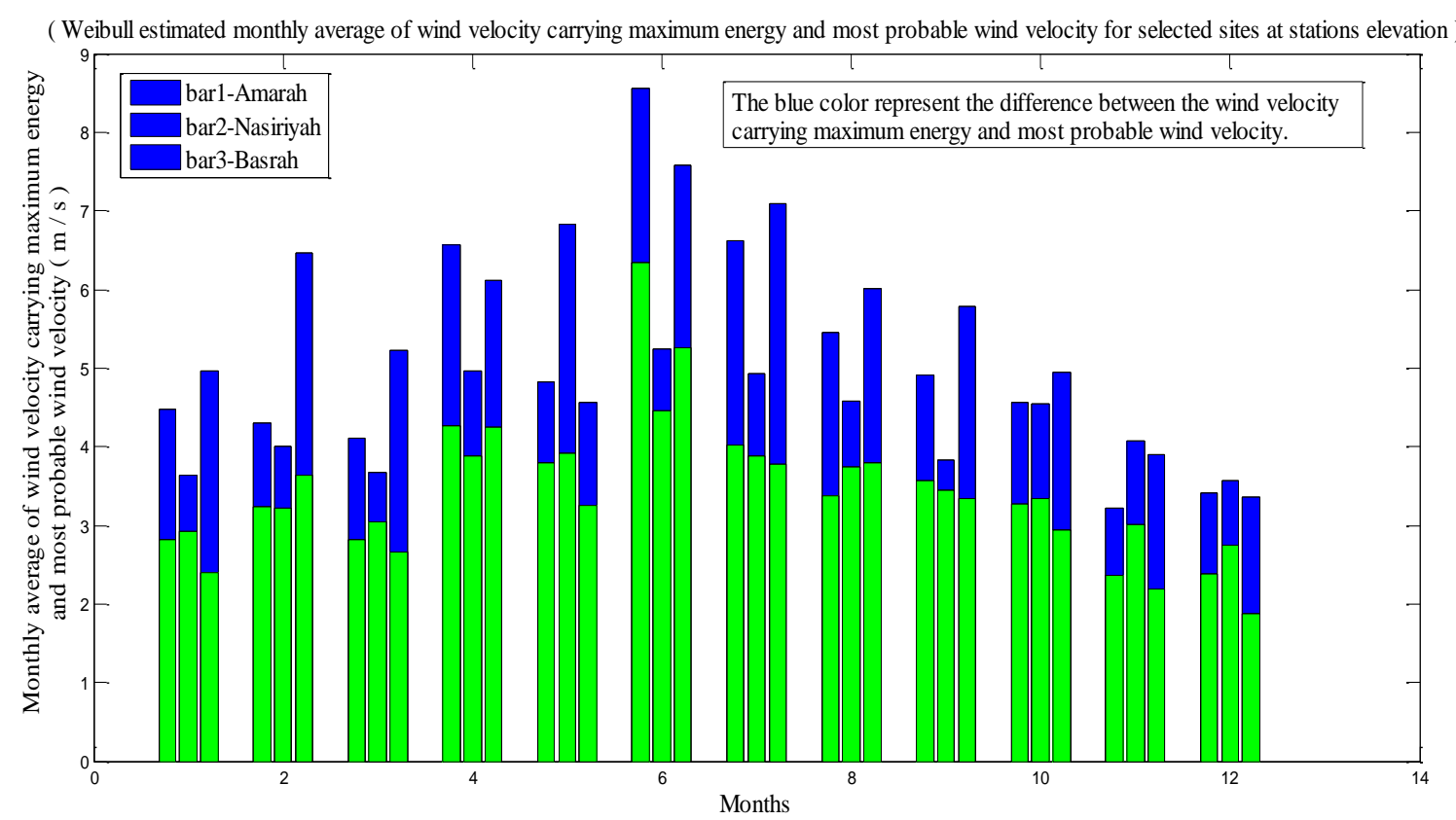

Fig 4: Monthly average of wind velocity carrying maximum energy and most probable wind velocity of selected sites at stations elevation. 


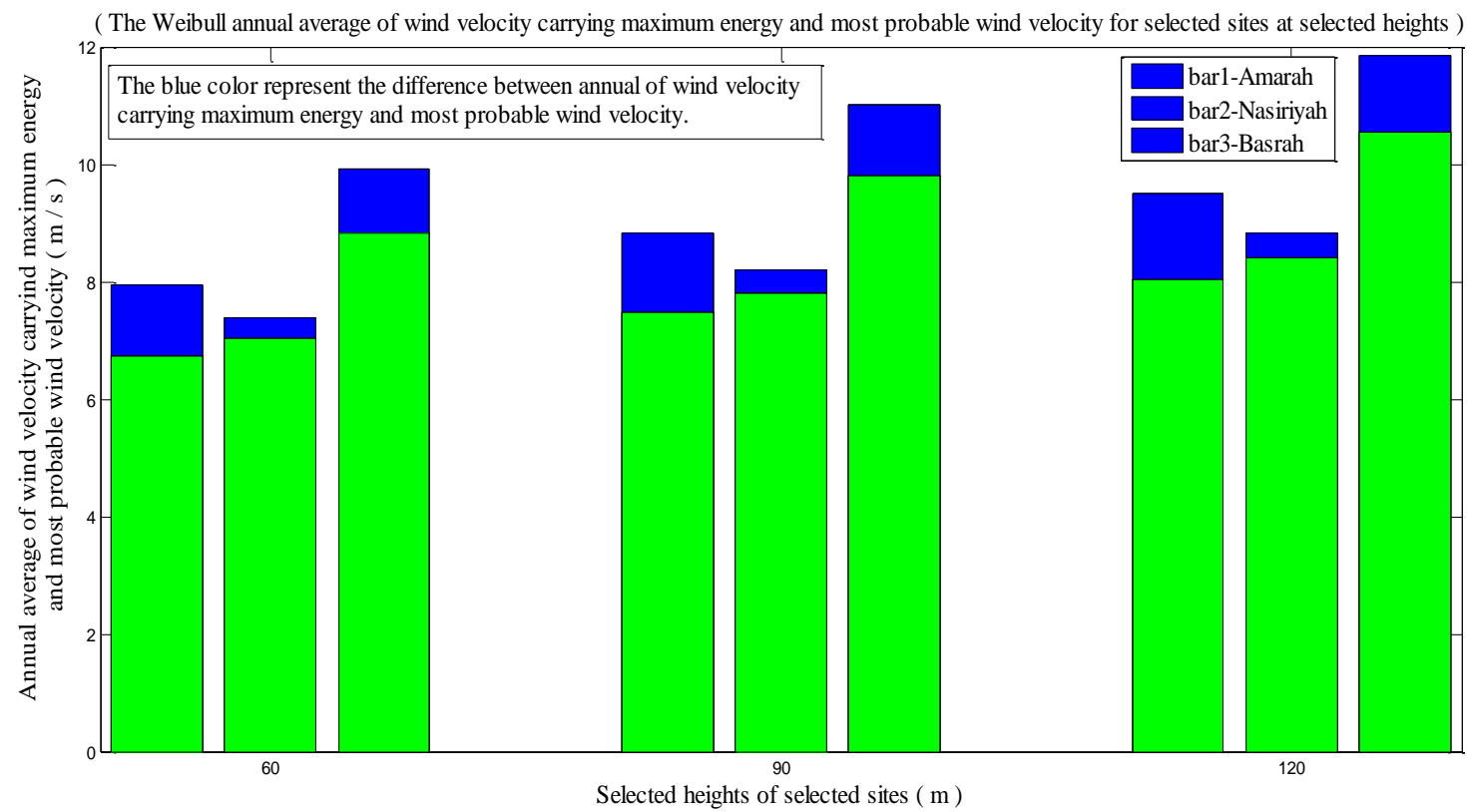

Fig 5: Annual average of wind velocity carrying maximum energy and most probable wind velocity of selected sites at selected heights.

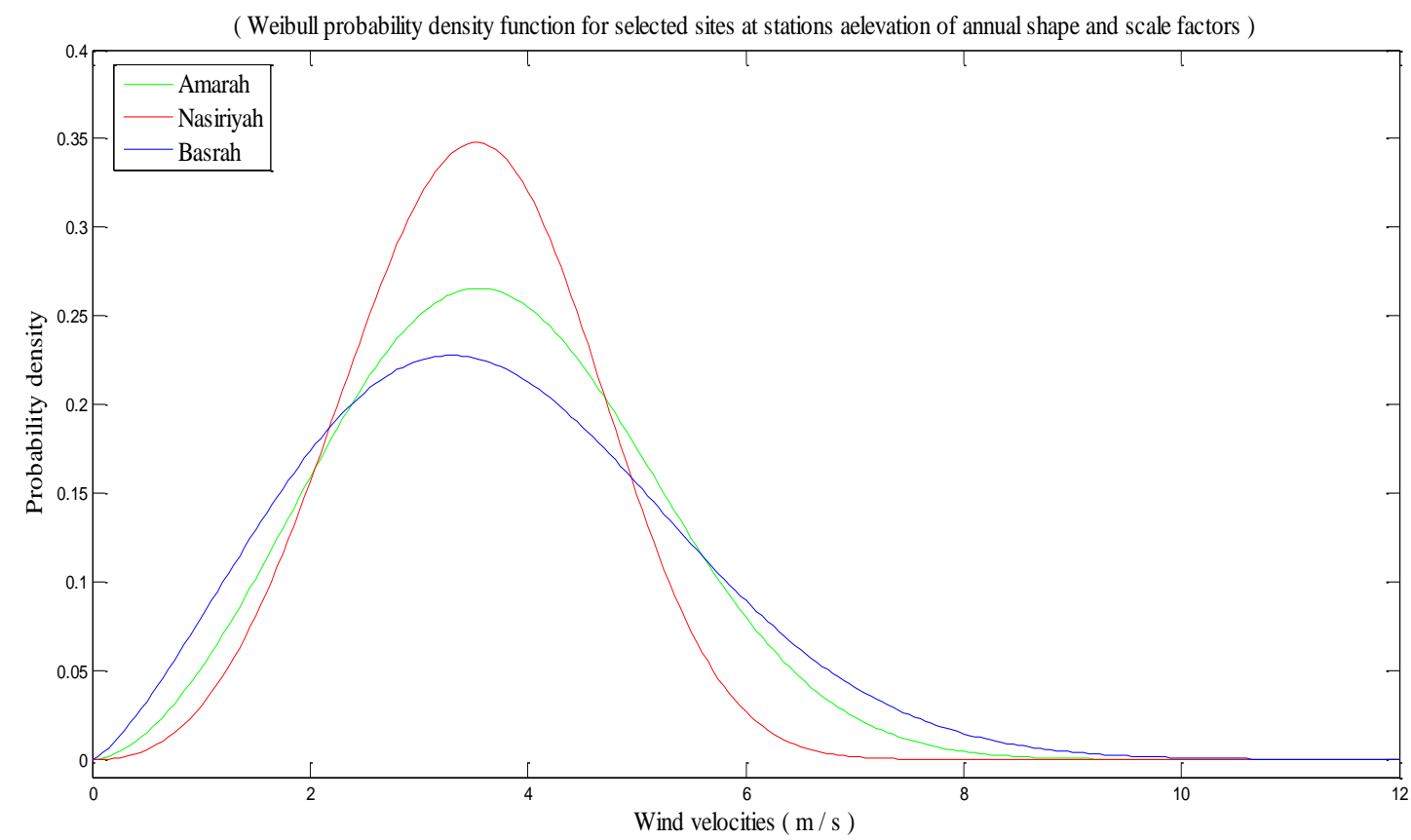

Fig 6: Weibull probability density function with wind velocity for selected sites at stations elevation of annual shape and scale factors. 


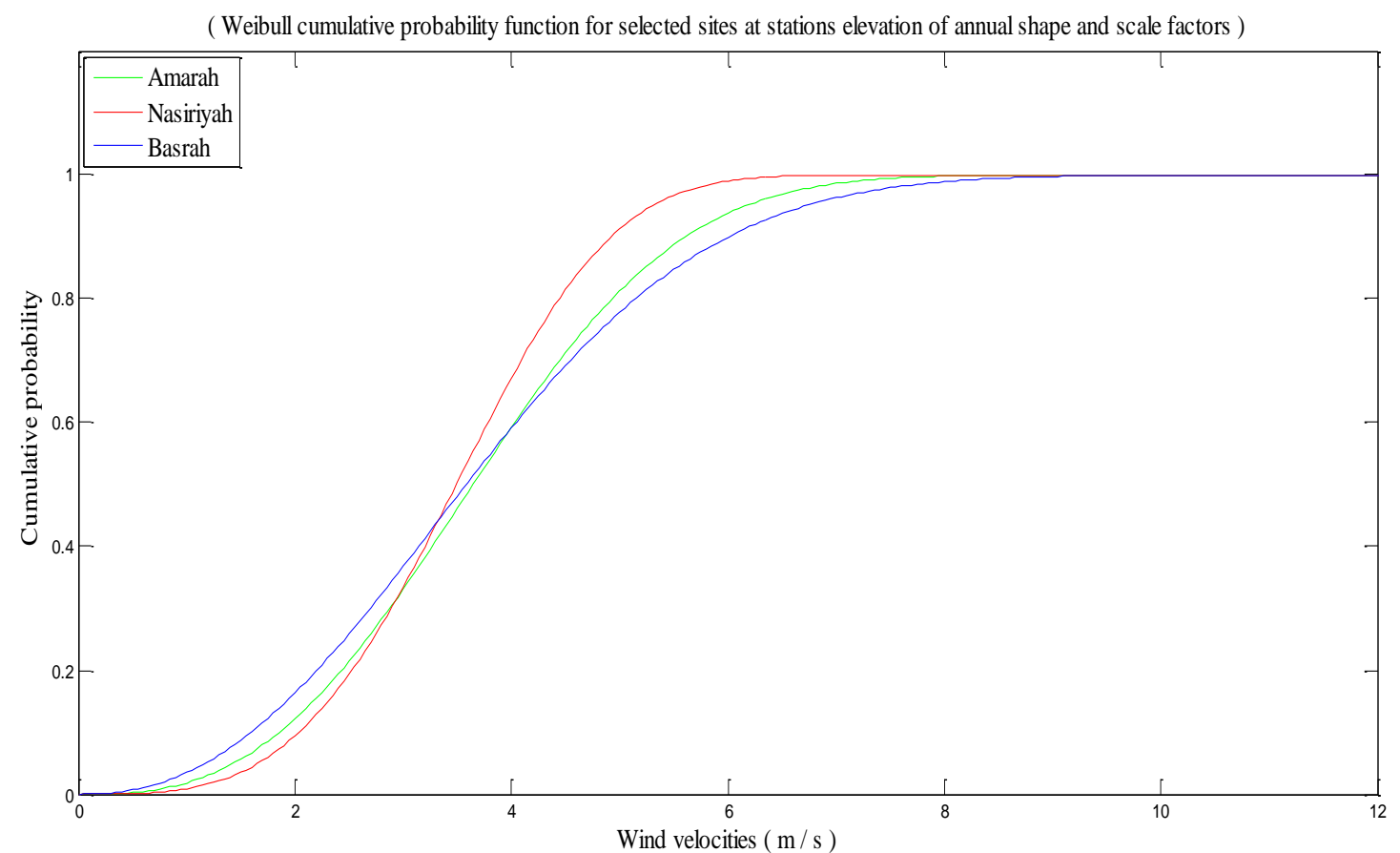

Fig 7: Weibull cumulative distribution function with wind velocity for selected sites at stations elevation of annual shape and scale factors.

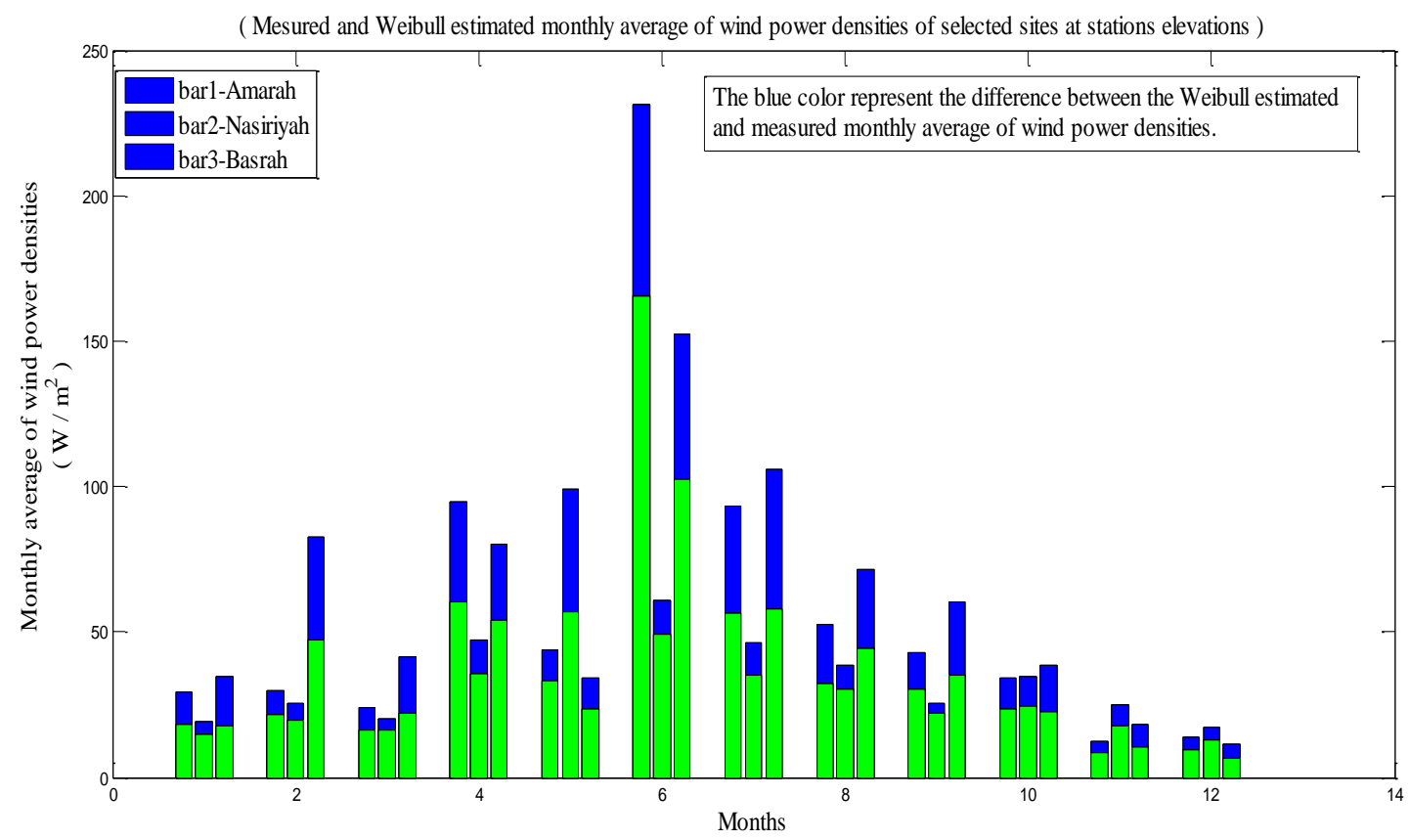

Fig 8: Monthly average for measured and Weibull estimated of wind power densities of selected sites at stations elevation. 


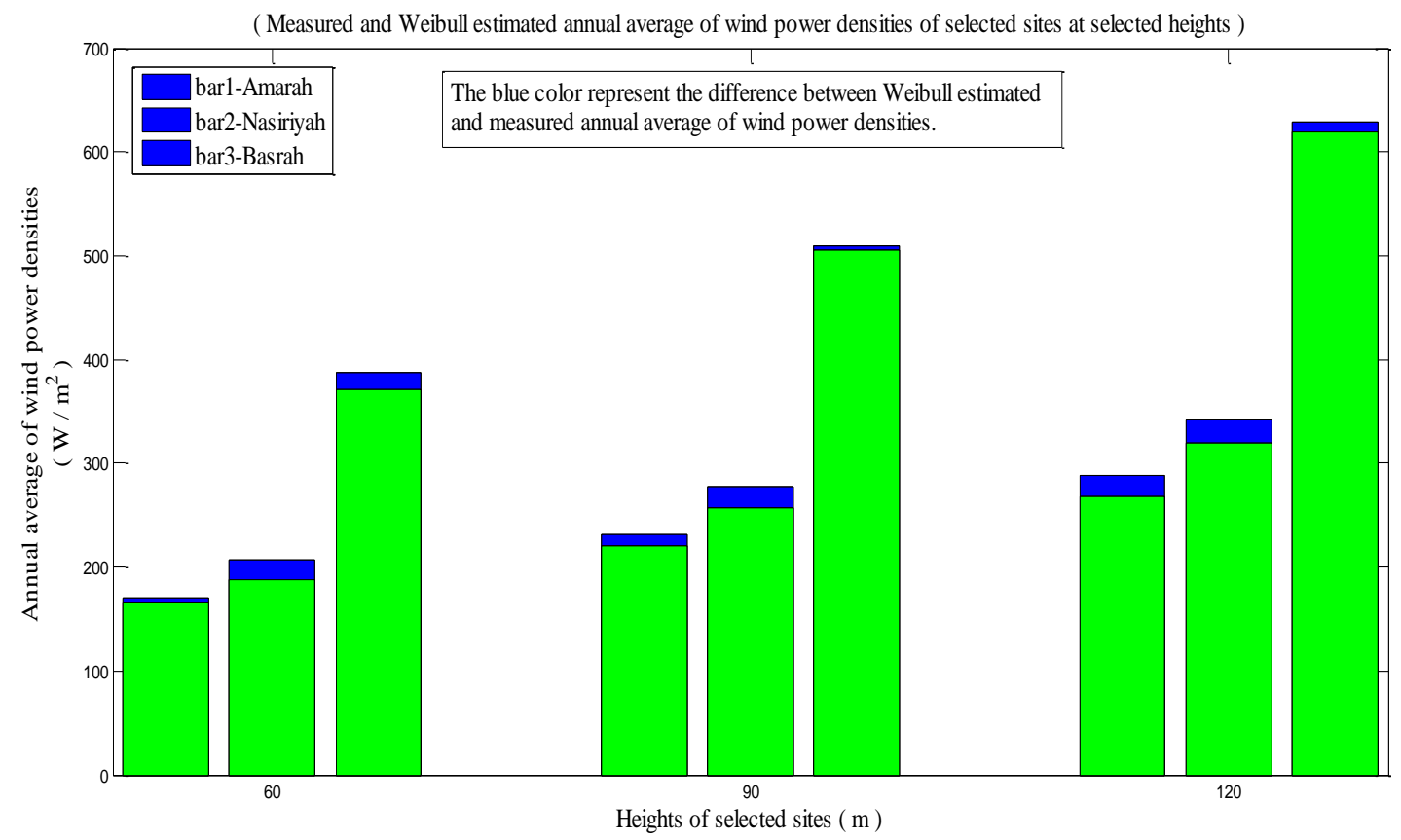

Fig 9: Annual average for measured and Weibull estimated of wind power densities of selected sites at selected heights.

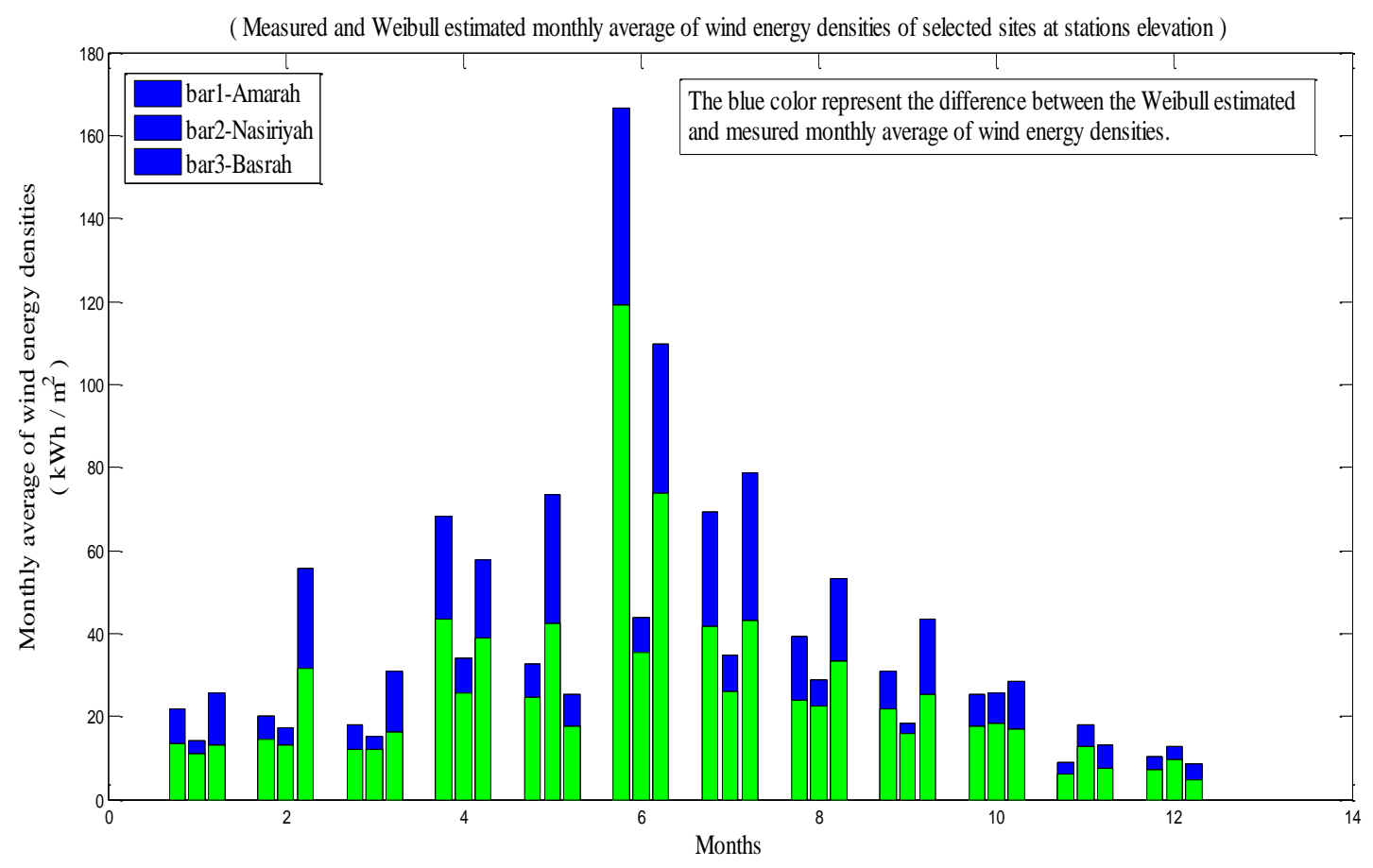

Fig 10: Monthly average for measured and Weibull estimated of wind energy densities of selected sites at stations elevation. 


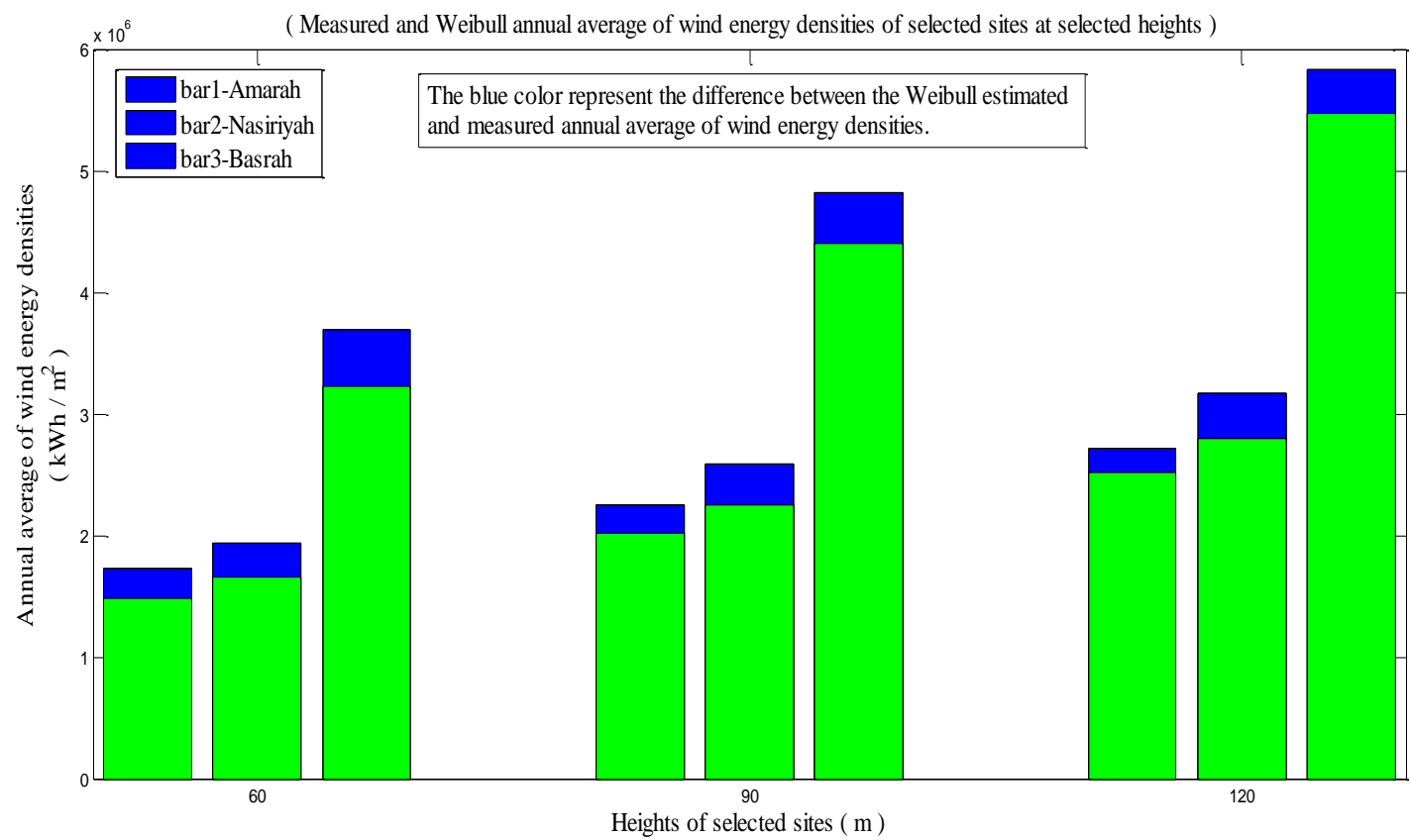

Fig 11: Annual average for measured and Weibull estimated of wind energy densities of selected sites at selected heights.

\section{REFERENCES}

[1] Shafiqur Rehman, and Aftab Ahmad, 2004, "Assessment of wind energy potential for coastal locations of the Kingdom of Saudi Arabia", Energy 29, PP. 1105-1115, doi:10.1016/j.energy.2004.02.026.

[2] Meishen Li, and Xianguo Li, 2005, "Investigation of Wind Characteristics and Assessment of Wind Energy Potential for Waterloo Region, Canada", Energy Conversion and Management 46, PP. 3014-3033.

[3] Getachew Bekele, and Björn Palm, 2009, "Wind Energy Potential Assessment at Four Typical Locations in Ethiopia", Applied Energy 86 PP. 388-396.

[4] Ioannis Fyrippis, Petros J. Axaopoulos, and Gregoris Panayiotou, 2010, "Wind Energy Potential Assessment in Naxos Island, Greece", Applied Energy 87, PP. 577-586.

[5] Joseph A. Jervase, and Ali M. Al-Lawati, 2012, "Wind Energy Potential Assessment for the Sultanate of Oman", Renewable and Sustainable Energy Reviews 16, 14961507.

[6] Sunday O Oyedepo, Muyiwa S Adaramola, and Samuel S Paul, 2012, "Analysis of wind speed data and wind energy potential in three selected locations in south-east Nigeria", International Journal of Energy and Environmental Engineering, 3:7, http://www.journalijeee.com/content/3/1/7.

[7] Saeed Jahanbakhsh Asl, Majid Rezaei Banafsheh, Yagob Dinpashoh, Marziyeh Esmaeilpour, Kasra Mohammadi, Ali Mohammad Khorshiddoust, 2014, "Assessing Wind Energy potential in Kurdistan Province, Iran", Int J
Energy Environ Eng, 5:100, DOI 10.1007/s40095-0140100-x.

[8] Oluseyi O Ajayi, Richard O Fagbenle, James Katende, Samson A Aasa and Joshua O Okeniyi, 2013, "Wind Profile Characteristics and Turbine Performance Analysis in Kano, North-Western Nigeria", International Journal of Energy and Environmental Engineering, 4:27, http://www.journal-ijeee.com/content/4/1/27.

[9] Farivar Fazelpour, Nima Soltani, Marc A. Rosen, 2014, "Wind Resource Assessment and Wind Power Potential for the City of Ardabil, Iran", Int J Energy Environ Eng, DOI 10.1007/s40095-014-0139-8.

[10] https://www.wunderground.com/global/stations/40680.ht $\mathrm{ml}$,

https://www.wunderground.com/global/stations/40676.ht $\mathrm{ml}$,

https://www.wunderground.com/global/stations/40689.ht $\mathrm{ml}$

[11] Sathyajith Mathew, 2006, "Wind Energy Fundamentals, Resource Analysis and Economics", (PP. 64, 68, 96, 71, 75,82 , and 83 ).

[12] Mukund R. Patel, 2006, "Wind and Solar Power Systems Design, Analysis, and Operation", $2^{\text {nd }}$ edition, (PP.31).

[13] Vaughn Nelson, 2009, "Wind Energy Renewable Energy and the Environment", (PP.37).

[14] David Wood, 2011, "Small Wind Turbines Analysis, Design, and Application" (PP. 14-15). 